\title{
E-cadherin expression and epidermal growth factor receptor mutation status predict outcome in non-small cell lung cancer patients treated with gefitinib
}

\author{
AKIHIKO MIYANAGA ${ }^{1,2}$, AKIHIKO GEMMA ${ }^{1}$, MASAHIRO ANDO $^{2}$, SEIJI KOSAIHIRA $^{1}$, \\ RINTARO NORO ${ }^{1}$, YUJI MINEGISHI ${ }^{1}$, KIYOKO KATAOKA ${ }^{1}$, MICHIYA NARA ${ }^{1}$, TETSUYA OKANO ${ }^{1}$, \\ HITOSHI MIYAZAWA ${ }^{3}$, TOMOAKI TANAKA ${ }^{3}$, AKINOBU YOSHIMURA ${ }^{1}$, KUNIHIKO KOBAYASHI $^{3}$, \\ HIROSHI IWANAMI ${ }^{2}$, KOICHI HAGIWARA ${ }^{3}$, EITAKA TSUBOI ${ }^{2}$ and SHOJI KUDOH ${ }^{1}$ \\ ${ }^{1}$ Department of Pulmonary Medicine/Infection and Oncology, Nippon Medical School, Tokyo; ${ }^{2}$ Tsuboi Cancer Center \\ Hospital, Fukushima; ${ }^{3}$ Department of Respiratory Medicine, Saitama Medical University, Saitama, Japan
}

Received October 3, 2007; Accepted November 15, 2007

\begin{abstract}
It is known that an epidermal growth factor receptor (EGFR) gene mutation(s) is present in a percentage of nonsmall cell lung cancers (NSCLCs). Gefitinib, an inhibitor of the tyrosine kinase activity of EGFR, is effective on most of them. The EGFR mutation status alone cannot fully predict the response to gefitinib and the prognosis for the patients. We hypothesized that information on the expression levels of phosphorylated-EGFR and -Akt, and E-cadherin, alone or in combination with information on the EGFR mutation, may refine our ability of prediction. We investigated 24 NSCLCs that had recurred after surgery and were treated with gefitinib. Specimens resected by surgery were subjected to the peptide nucleic acid-locked nucleic acid polymerase chain reaction clamp reaction to determine the EGFR mutation status, and to immunohistochemical staining of phosphorylated-EGFR and -Akt, and E-cadherin to determine their expression levels. The EGFR mutation status was predictive of responsive disease (complete response: $\mathrm{CR}+$ partial response: $\mathrm{PR})$ and controlled disease $(\mathrm{CR}+\mathrm{PR}+$ stable disease: SD). Positive E-cadherin staining was predictive of longer time to progression (12.4 vs. 5.9 months, $\mathrm{p}<0.05)$ and overall survival (OS) (18.4 vs. 13.0 months, $\mathrm{p}<0.05)$. Together the patients with an EGFR mutation and the patients with positive E-cadherin staining defined a patient group with a median OS of 18.4 months and excluded the patient group with the median OS of 3.7 months. Neither p-Akt nor p-EGFR staining was associated with the response and survival. In
\end{abstract}

Correspondence to: Dr Akihiko Gemma, The Department of Pulmonary Medicine/Infection and Oncology, Nippon Medical School, 1-1-5 Sendagi, Bunkyo-ku, Tokyo 113-8602, Japan E-mail: agemma@nms.ac.jp

Key words: non-small cell lung cancer, gefitinib, E-cadherin, epidermal growth factor receptor mutation patients with surgically resected NSCLC tumors, the EGFR mutation status and E-cadherin staining can select patients who will benefit from gefitinib therapy.

\section{Introduction}

Gefitinib (ZD1839, Iressa, AstraZeneca, Wilmington, DE) is a therapeutic reagent for non-small cell lung cancers (NSCLCs). It shows dramatic anti-tumor effects in some patients, but has no effect in others (1). The presence of an epidermal growth factor receptor (EGFR) gene mutation(s) (hereafter EGFR mutation) associates significantly with the gefitinib responsiveness $(2,3)$ and serves as a marker in the choice of therapeutic regimens (4). Some tumors with an EGFR mutation do not respond to gefitinib therapy while those with wild-type gene do (5-7), so additional markers are required to more precisely select tumors that respond to gefitinib.

EGFR transmits signals that direct cell proliferation and survival. The wild-type EGFR preferentially transmits cell proliferation signals through Erk, while the mutant EGFR preferentially transmits cell survival signals through Akt or STAT (8). Gefitinib effectively inhibits the latter (2). This is why gefitinib selectively elicits an apoptotic response in cells with an EGFR mutation, thereby producing its clinical response (8). We hypothesized that molecules that interact with EGFR or are located downstream in the pathway modify the tumor cell response to gefitinib and therefore serve as markers that may help to more precisely predict their responsiveness to gefitinib.

In this study, three molecules were tested for their predictive ability, p-EGFR (phosphorylated at Tyr1173: pTyr1173), p-Akt (phosphorylated at Ser473: pSer473) and E-cadherin, in addition to the EGFR mutation status. pEGFR(pTyr1173) transmits a signal that directs cell proliferation (9), p-Akt(pSer473) mediates signals that direct cell survival (10) and E-cadherin has been shown to interact with EGFR by modifying its activity (11). We investigated the expressions of these three molecules by immunohistochemistry 
in 24 NSCLCs that had been resected by surgery, recurred afterward and were treated with gefitinib. The results enabled us to test their staining intensity, alone, or in combination with the EGFR mutation status. It also improved our ability to predict the responsiveness to gefitinib and patient outcome.

\section{Materials and methods}

Patients. This study was approved by the Tsuboi Cancer Center Hospital ethics board. After the written informed consent was obtained, we enrolled 24 Japanese patients who had suffered from lung cancers which were resected between 1996 and 2004 (Tsuboi Cancer Center Hospital, Fukushima, Japan) and then had recurred. The patient characteristics are summarized in Table I. Gefitinib, $250 \mathrm{mg}$ per day, was initiated between July 2002 and October 2006 to treat the recurrent disease. The median time between the surgery and the start of the gefitinib treatment was 740 days (range: 113-2.012). Treatment was continued until the disease progressed, intolerable toxicity developed or a patient refused treatment for other reasons.

Evaluation of the response to gefitinib and patient outcome. Every 4 weeks chest X-rays or computed tomography (CT) scans were done to evaluate tumor response and lung toxicity, and blood tests were done to monitor systemic toxicity. Tumor response that remained stable for at least 30 days was graded according to the Response Evaluation Criteria in Solid Tumors (12). Time to progression (TTP) in these patients was defined as the interval from the start of gefitinib administration to disease progression or death. The outcomes were evaluated up to May 31, 2007, with an average followup time of 20.6 months (range: 1.1-50.0). Both mutation and immunohistochemical analyses were performed after completion of the response evaluation.

DNA extraction and mutation analysis. DNA was extracted from the paraffin-embedded tumor tissue (13-15). EGFR mutations were detected using the peptide nucleic acidlocked nucleic acid (PNA-LNA) polymerase chain reaction (PCR) clamp. This method, which has been described in detail elsewhere, is a rapid and sensitive detection system for EGFR gene mutations and can detect point mutations G719C, G719S, L858R and L861Q and deletions in exon 19 in the presence of a 100- to 1.000-fold background of wild-type EGFR $(4,6,16)$.

Immunohistochemistry and scoring. Formalin-fixed, paraffinembedded tumor tissue was tested for immunoreactivity to pEGFR, p-Akt and E-cadherin. The primary antibodies used were: anti-p-EGFR that detects EGFR protein phosphorylated at Tyr1173 (Cell Signaling Technology Beverly, MA), antip-Akt that detects Akt protein phosphorylated at Ser473 (Cell Signaling Technology) and anti-E-cadherin (BD Biosciences, Beverly, MA). Tissue sections cut at a thickness of $5 \mu \mathrm{m}$ were placed on glass slides, deparaffinized and then rehydrated. Antigen was quantified using the following procedure. The slides were incubated in citrate buffer in a steamer for $15 \mathrm{~min}$. Endogenous peroxidase activity was quenched by incubating the slides in $3 \%$ hydrogen peroxide for $5 \mathrm{~min}$ and non-specific background staining was blocked by incubation in a protein
Table I. Patient characteristics.

\begin{tabular}{|c|c|c|}
\hline Characteristic & $\begin{array}{l}\text { No. of patients } \\
\quad(n=24)\end{array}$ & $\%$ \\
\hline \multicolumn{3}{|l|}{ Gender } \\
\hline Male & 13 & 54.2 \\
\hline Female & 11 & 45.8 \\
\hline Median age, years (range) & 63.2 & $(44-84)$ \\
\hline \multicolumn{3}{|l|}{ ECOG performance status } \\
\hline 0 & 6 & 25.0 \\
\hline 1 & 18 & 75.0 \\
\hline \multicolumn{3}{|l|}{ Histology } \\
\hline Adenocarcinoma & 21 & 87.5 \\
\hline Squamous cell carcinoma & 1 & 4.2 \\
\hline $\begin{array}{l}\text { Adenosquamous cell } \\
\text { carcinoma }\end{array}$ & 2 & 8.4 \\
\hline \multicolumn{3}{|l|}{ Prior chemotherapy } \\
\hline $0-1$ regimens & 18 & 75.0 \\
\hline$>2$ regimens & 6 & 25.0 \\
\hline \multicolumn{3}{|l|}{ Smoking history } \\
\hline Never smoked & 19 & 79.2 \\
\hline Smoker (current/former) & 5 & 20.8 \\
\hline \multicolumn{3}{|l|}{ Stage } \\
\hline I-II & 19 & 79.2 \\
\hline III-IV & 5 & 20.8 \\
\hline
\end{tabular}

ECOG, Eastern Cooperative Oncology Group.

block for $5 \mathrm{~min}$. Sections were then reacted with primary antibody dilutions (p-EGFR a $1 / 400$ dilution at $37^{\circ} \mathrm{C}$ for $15 \mathrm{~min}$, p-Akt a $1 / 50$ dilution at $4^{\circ} \mathrm{C}$ for $16 \mathrm{~h}$ and E-cadherin a $1 / 100$ dilution at $37^{\circ} \mathrm{C}$ for $32 \mathrm{~min}$ ). The bound antibody was detected by biotinylated secondary antibody and visualized using diaminobenzidine (DAB) chromogen. Sections were then counterstained with Mayer's hematoxylin and mounted using the resinous mounting medium.

The p-EGFR and p-Akt stainings were scored by their cytoplasmic and nuclear staining, while E-cadherin staining was scored by its membrane staining (17-19), all without the knowledge of clinical or laboratory information. The cytoplasmic and nuclear staining of the entire tumor was scored as follows: First, 500 randomly selected tumor cells (50 cells per randomly chosen microscopic field at x40 magnification) were scored as 0 (no staining), 1 (mild), 2 (moderate) or 3 (strong staining). Second, for p-EGFR, the most intense staining observed in $>1 \%$ of the cells was the staining score for the tumor. For p-Akt, the mode of the cytoplasmic or nuclear staining score, whichever was greater, was the staining score for the tumor. Tumors with staining scores of 0 or 1 were ranked negative and scores of 2 or 3 were ranked positive. The membrane staining of the entire tumor was scored as 0 when no tumor cells were stained, 1 when $<10 \%$ 
Table II. Response to gefitinib therapy.

\begin{tabular}{lccccc}
\hline & CR & PR & SD & PD & NE \\
\hline $\begin{array}{l}\text { No. of patients } \\
\begin{array}{l}\text { Median TTP } \\
\text { (months) }\end{array}\end{array}$ & 0 & 8 & 6 & 5 & 5 \\
$\begin{array}{l}\text { Median OS } \\
\text { (months) }\end{array}$ & 16.1 & 9.3 & 1.0 & \\
\hline
\end{tabular}

TTP, time to progression; OS, overall survival; CR, complete response; $\mathrm{PR}$, partial response; $\mathrm{SD}$, stable disease; $\mathrm{PD}$, progressive disease; NE, not evaluated.

showed weak membrane staining, 2 (weakly positive) when $>10 \%$ showed complete membrane staining although with weak to moderate intensity and 3 (strongly positive) when $>10 \%$ had complete and strong membrane staining. Entire tumors with staining scores of 0 or 1 were considered negative while those scored as 2 or 3 were considered positive.

Statistical analyses. All statistical analyses were performed by StatView version 5 software (SAS institute Inc, Cary, NC). Comparisons of the proportions between two populations utilized the $\chi^{2}$ test. Comparisons of patient outcome (TTP and overall survival, OS) between patient groups utilized the Kaplan-Meier method and the log-rank test. All statistical tests were two-sided and $\mathrm{P}<0.05$ was considered significant.

\section{Results}

Response to the gefitinib and patient outcome. The responses to gefitinib are summarized in Table II. The responders [complete response: $\mathrm{CR}+$ partial response: PR, (8/24) 33\%] had significantly longer TTP and OS than non-responders $(\mathrm{p}<0.005$ and $\mathrm{p}<0.05$, respectively). In addition, the patients with controlled disease [CR + PR + stable disease: SD (13/24) $54 \%$ ] had significantly longer TTP and OS $(\mathrm{p}<0.001$ and $\mathrm{p}<0.001$, respectively). We found no significant differences in the OS between patients with PR and SD nor could we prove that $\mathrm{CR}+\mathrm{PR}$ better defined patients who benefited from the therapy than $\mathrm{CR}+\mathrm{PR}+\mathrm{SD}$. We therefore performed the analyses based on the two groupings.

Analyses of the EGFR mutation status and staining of p-EGFR, $p$-Akt and E-cadherin. We investigated the EGFR mutation status and the staining of p-EGFR, p-Akt and E-cadherin. We chose these proteins because they are intimately connected with the activity of EGFR and thus may predict responsiveness to gefitinib and/or patient outcome. In the mutation analysis, 10 patients were found to have an EGFR mutation: one had a point mutation L858R(T2573G), two had a deletion E746A750del(2235-2249del), six had a deletion E746-A750del (2236-2250del), and one had a deletion L747-S752del, P753S(2240-2257del). All these mutations have been observed in gefitinib responders in the literature $(2,3)$. Representative immunohistochemical staining is shown in Fig. 1 with the results summarized in Table III. The results of the EGFR mutation status are also shown. Positive p-Akt staining was associated with EGFR mutation, which is plausible because mutant EGFR stimulates the cell survival signal that is mediated by p-Akt. The staining intensity of p-EGFR and Ecadherin failed to show an association with the EGFR mutation and thus may be an independent parameter.

Predictors of the responsiveness to gefitinib. We then investigated the association between the expression of these proteins and the responsiveness to gefitinib (Table IV). The presence of an EGFR mutation significantly associates with responsive diseases $(\mathrm{CR}+\mathrm{PR})$ or controlled diseases $(\mathrm{CR}+$ $\mathrm{PR}+\mathrm{SD})$. This is consistent with the results presented in previous reports (20-22). We found no significant associations in the staining result for p-EGFR, p-Akt and E-cadherin.

Predictors of patient outcome. We compared the KaplanMeier curves to identify predictors of longer TTP and/or OS. As shown in Fig. 2A the positive staining of E-cadherin predicts a longer TTP (12.4 vs. 5.9 months, $\mathrm{p}<0.05)$ and longer OS (18.4 vs. 13.0 months, $\mathrm{p}<0.05)$. The presence of EGFR mutation(s) ( $\mathrm{p}=0.13$ and $\mathrm{p}=0.11$, respectively, Fig. $2 \mathrm{~B})$, as well as p-EGFR and p-Akt staining intensity failed to predict outcome. We then looked at the EGFR mutation status in conjunction with the E-cadherin staining intensity as predictors of these same parameters. As shown in Fig. $2 \mathrm{C}$ in the right panel, the patients with EGFR mutation-positive tumors and those with E-cadherin-positive tumors defined a patient group with a median OS of 18.4 months and excluded the patient group with the median OS of 3.7 months, although we failed to show a significant difference in TTP (Fig. 2C, left panel). Therefore, we consider that the patients with EGFR mutation-positive or E-cadherin-positive tumors are the most likely to benefit from gefitinib therapy.

\section{Discussion}

It was shown that NSCLC tumors with an EGFR mutation(s) respond to gefitinib at a rate of 65 to $100 \%(5-7,20-24)$. Several prospective phase II studies have shown that gefitinib therapy significantly lengthened TTP in NSCLC patients with EGFR mutation-positive tumors (5-7). Thus far, no prospective studies have reported on OS. Several retrospective studies have suggested that gefitinib therapy may result in a longer OS in patients with EGFR mutation-positive tumors $(20,21,23)$, however, we did not observe any significant differences in either TTP or OS. This is likely due to the size of the current study, as is discussed later.

We showed that positive E-cadherin staining is significantly associated with TTP and OS. Possible mechanisms that may explain this observation include that i) tumors with a lower E-cadherin expression progress faster than those with a higher expression and ii) E-cadherin modifies EGFR function and thus contributes to the effect of gefitinib treatment. The former mechanism is supported in reports that show that tumors with a positive E-cadherin staining are more frequent in early stage than in locally advanced or metastasizing NSCLCs (25-28). Similar results have been obtained in other malignancies such as the esophagus $(29,30)$, stomach $(31,32)$, colon $(33)$, 


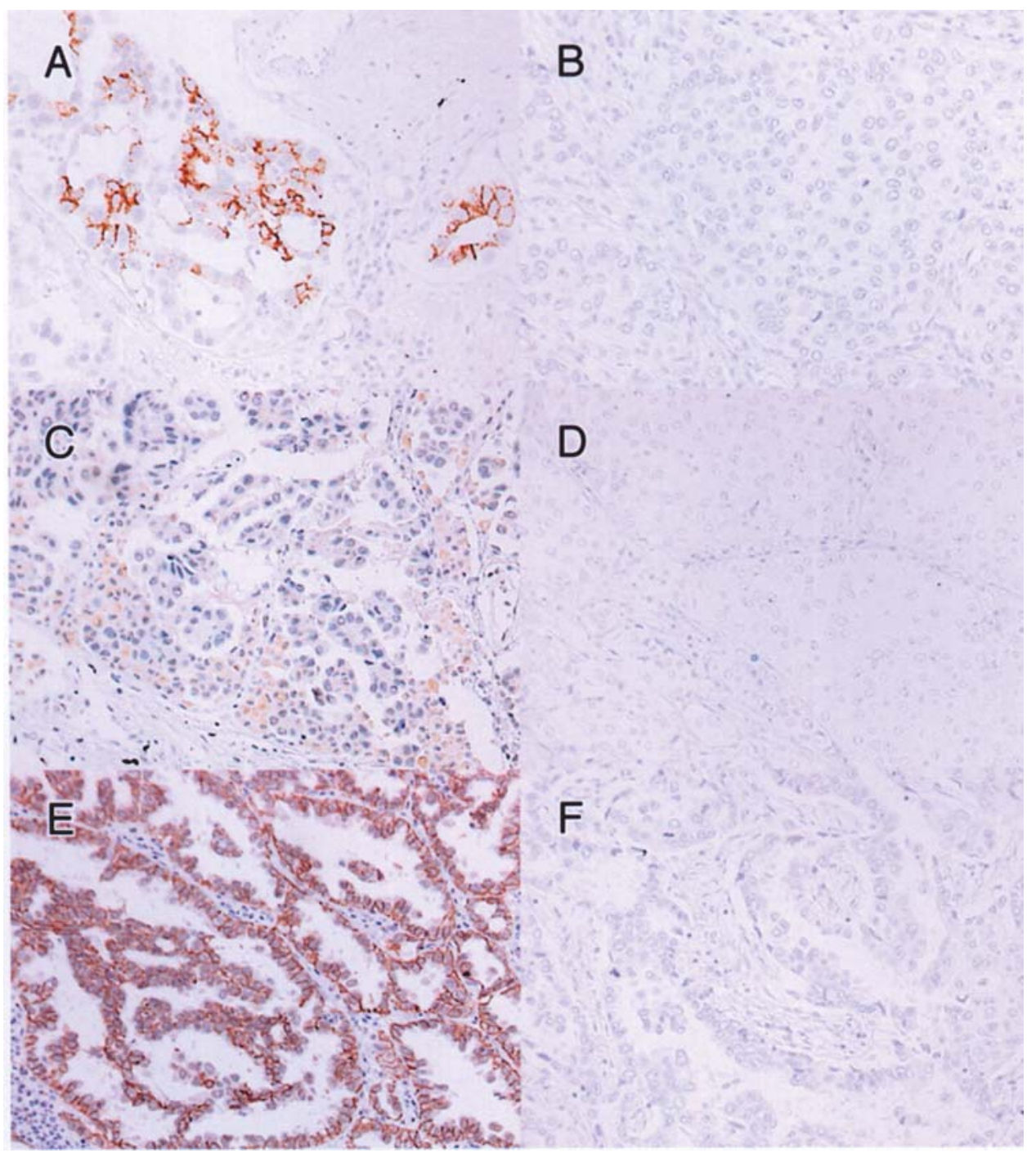

Figure 1. Immunohistochemistry. Positive (A) and negative (B) staining for p-EGFR; positive (C) and negative (D) staining for p-Akt; positive (E) and negative (F) staining for E-cadherin; magnification, x200.

Table III. EGFR mutation and staining of p-EGFR, p-Akt and E-cadherin.

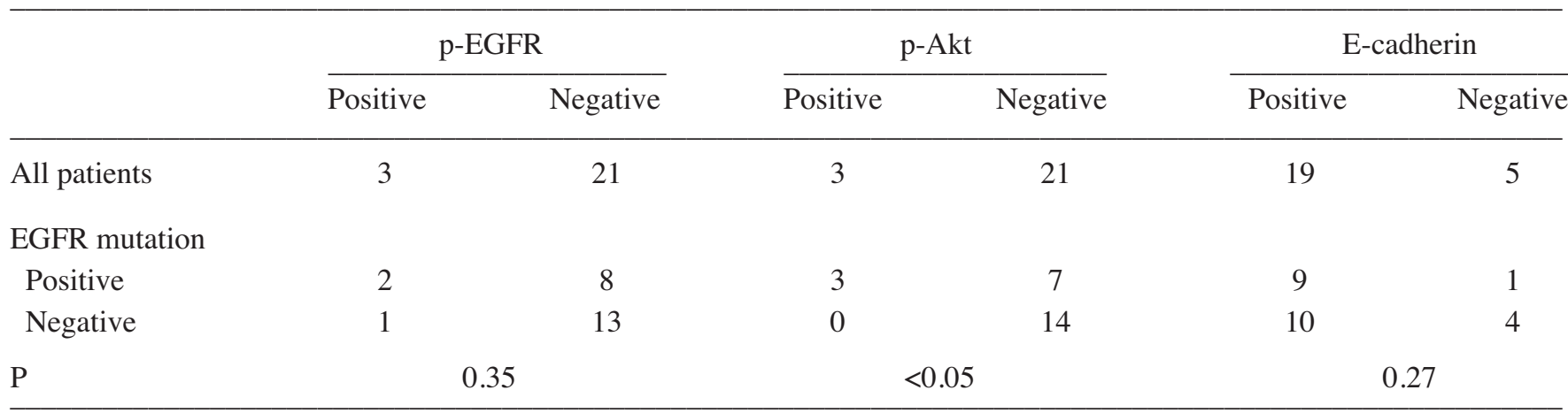

EGFR, epidermal growth factor receptor; p-EGFR, phosphorylated-EGFR; p-Akt, phosphorylated-Akt.

liver (34), pancreas (35) and urinary bladder $(36,37)$. Moreover, in NSCLCs, a positive E-cadherin expression associates with a more differentiated histology $(26,28)$ and a better prognosis $(25,27,28)$. The latter mechanism is supported by reports showing that E-cadherin interacts with EGFR, thereby decreasing ligand-affinity $(38,39)$ and inhibiting activation (40) in several human tumor types including the esophageal, breast and lung (41-43). Mechanisms i) and ii) stated above are not mutually exclusive and both may contribute to a better prognosis. 
A
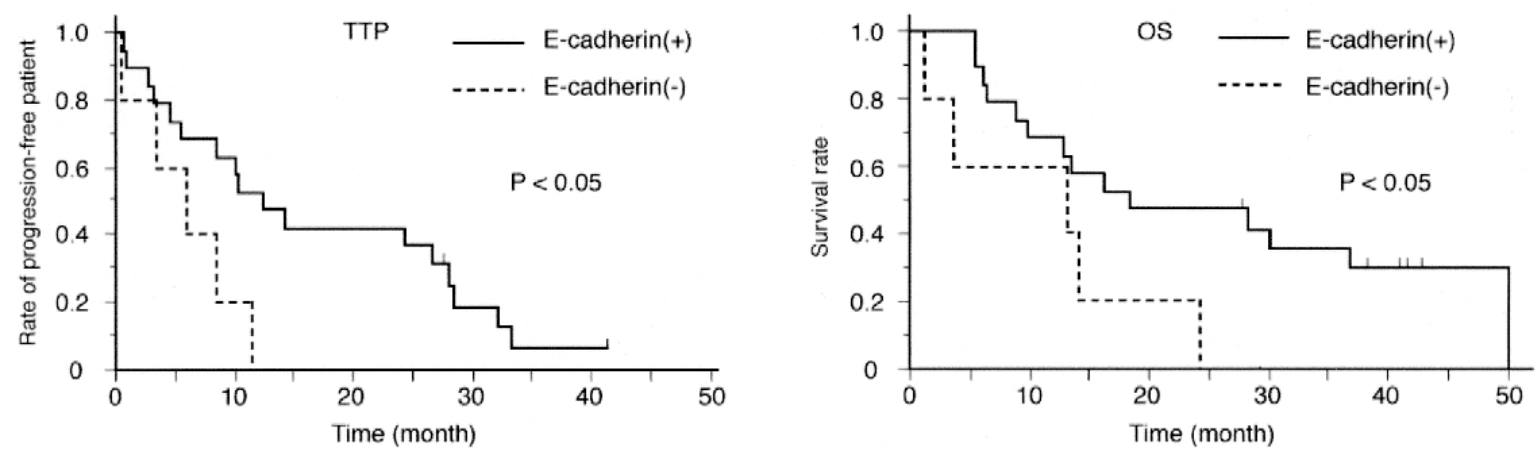

B
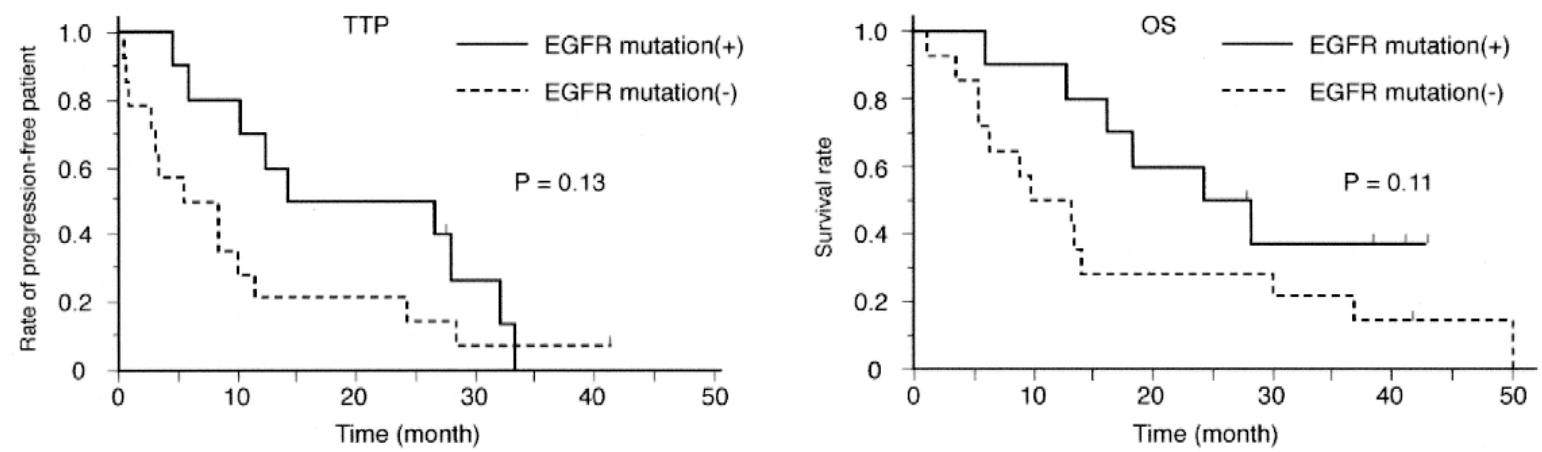

C
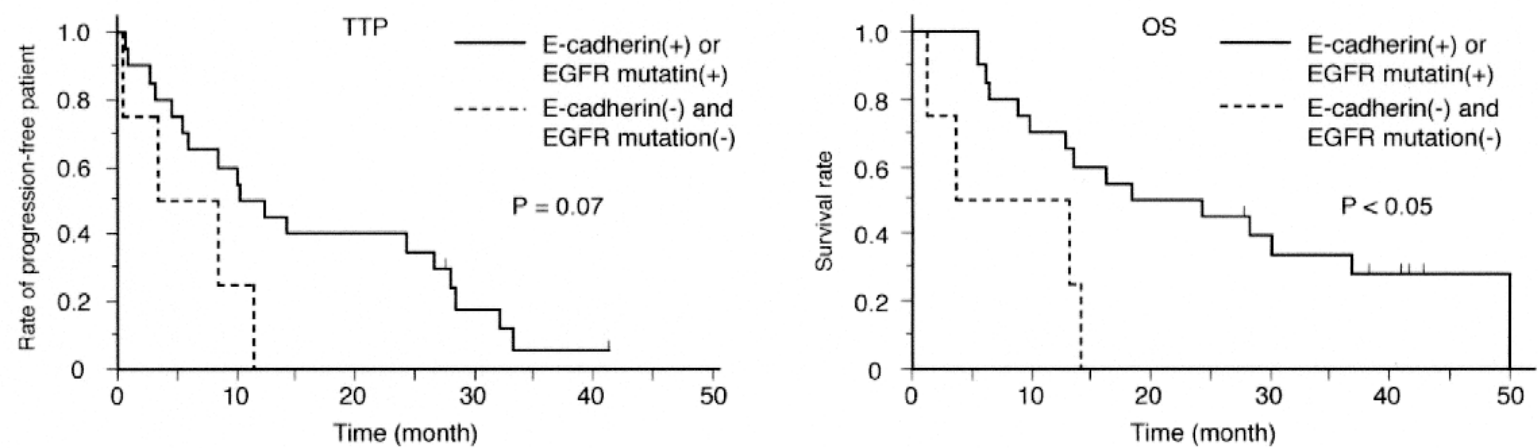

Figure 2. (A) Kaplan-Meier plots of TTP and OS where patients are grouped by the E-cadherin staining of their tumors. (B) Kaplan-Meier plots of TTP and OS where patients are grouped by the EGFR mutation status of their tumors. (C) Kaplan-Meier plots of TTP and OS where the two groups of patients have i) tumors which stain positively for E-cadherin or have an EGFR mutation(s) and ii) tumors which are negative for E-cadherin staining and EGFR mutation.

Table IV. Gefitinib response summarized by the EGFR mutation status and by the staining of p-EGFR, p-Akt or E-cadherin.

\begin{tabular}{|c|c|c|c|c|c|c|c|c|}
\hline & \multicolumn{2}{|c|}{ EGFR mutation } & \multicolumn{2}{|c|}{ p-EGFR } & \multicolumn{2}{|c|}{ p-Akt } & \multicolumn{2}{|c|}{ E-cadherin } \\
\hline & Positive & Negative & Positive & Negative & Positive & Negative & Positive & Negative \\
\hline All patients & 10 & 14 & 3 & 21 & 3 & 21 & 19 & 5 \\
\hline $\begin{array}{l}\text { Responsive disease } \\
(\mathrm{CR}+\mathrm{PR})\end{array}$ & 6 & 2 & 1 & 7 & 1 & 7 & 6 & 2 \\
\hline $\mathrm{P}$ & \multicolumn{2}{|c|}{$<0.005$} & \multicolumn{2}{|c|}{0.23} & \multicolumn{2}{|c|}{0.23} & \multicolumn{2}{|c|}{0.72} \\
\hline $\begin{array}{l}\text { Controlled disease } \\
(\mathrm{CR}+\mathrm{PR}+\mathrm{SD})\end{array}$ & 7 & 7 & 1 & 13 & 1 & 13 & 11 & 3 \\
\hline $\mathrm{P}$ & \multicolumn{2}{|c|}{$<0.05$} & \multicolumn{2}{|c|}{0.54} & \multicolumn{2}{|c|}{0.54} & \multicolumn{2}{|c|}{0.95} \\
\hline
\end{tabular}

EGFR, epidermal growth factor receptor; p-EGFR, phosphorylated-EGFR; p-Akt, phosphorylated-Akt. 
The current study warrants a larger one and presents an important question. We have six panels in Fig. 2, three of which showed significant differences and three of which did not. It is calculated that, if twice as many patients had been enrolled and had shown similar responsiveness and prognoses, all six sets of the two groups compared in Fig. 2 would have shown significant differences. To investigate this, a study should be scheduled where more than twice the number of patients is enrolled. We showed that tumors with a positive E-cadherin staining have a better prognosis after gefitinib therapy. It is, however, not clear whether the E-cadherin expression and EGFR mutation(s) contribute to it independently or synergistically. Basic and clinical researches addressing this issue may provide important information on the role of E-cadherin and EGFR in carcinogenesis.

\section{Acknowledgements}

We would like to thank Dr Yoshiaki Nagai, Department of Respiratory Medicine, Saitama Medical University, for his technical suggestions. We also thank Dr Yutaka Hatanaka, Dako, Japan, for his assistance in immunohistochemical analyses. This study was supported in part by a Grant-in-Aid from the Ministry of Education, Culture, Sports, Science and Technology of Japan and by a Grant-in-Aid from the Japan Society for the Promotion of Science.

\section{References}

1. Fukuoka M, Yano S, Giaccone G, Tamura T, Nakagawa K, Douillard JY, Nishiwaki Y, Vansteenkiste J, Kudoh S, Rischin D, Eek R, Horai T, Noda K, Takata I, Smit E, Averbuch S, Macleod A, Feyereislova A, Dong RP and Baselga J: Multiinstitutional randomized phase II trial of gefitinib for previously treated patients with advanced non-small-cell lung cancer (the IDEAL 1 trial). J Clin Oncol 21: 2237-2246, 2003.

2. Lynch TJ, Bell DW, Sordella R, Gurubhagavatula S, Okimoto RA, Brannigan BW, Harris PL, Haserlat SM, Supko JG, Haluska FG, Louis DN, Christiani DC, Settleman J and Haber DA: Activating mutations in the epidermal growth factor receptor underlying responsiveness of non-small-cell lung cancer to gefitinib. N Engl J Med 350: 2129-2139, 2004.

3. Paez JG, Janne PA, Lee JC, Tracy S, Greulich H, Gabriel S, Herman P, Kaye FJ, Lindeman N, Boggon TJ, Naoki K, Sasaki H, Fujii Y, Eck MJ, Sellers WR, Johnson BE and Meyerson M: EGFR mutations in lung cancer: correlation with clinical response to gefitinib therapy. Science 304: 1497-1500, 2004.

4. Tanaka T, Nagai Y, Miyazawa H, Koyama N, Matsuoka S, Sutani A, Huqun, Udagawa K, Murayama Y, Nagata M, Shimizu Y, Ikebuchi K, Kanazawa M, Kobayashi K and Hagiwara K: Reliability of the peptide nucleic acid-locked nucleic acid polymerase chain reaction clamp-based test for epidermal growth factor receptor mutations integrated into the clinical practice for non-small cell lung cancers. Cancer Sci 98: 246-252, 2007.

5. Inoue A, Suzuki T, Fukuhara T, Maemondo M, Kimura Y, Morikawa N, Watanabe H, Saijo Y and Nukiwa T: Prospective phase II study of gefitinib for chemotherapy-naive patients with advanced non-small-cell lung cancer with epidermal growth factor receptor gene mutations. J Clin Oncol 24: 3340-3346, 2006.

6. Sutani A, Nagai Y, Udagawa K, Uchida Y, Koyama N, Murayama Y, Tanaka T, Miyazawa H, Nagata M, Kanazawa M, Hagiwara K and Kobayashi K: Gefitinib for non-small-cell lung cancer patients with epidermal growth factor receptor gene mutations screened by peptide nucleic acid-locked nucleic acid PCR clamp. Br J Cancer 95: 1483-1489, 2006.

7. Asahina H, Yamazaki K, Kinoshita I, Sukoh N, Harada M, Yokouchi H, Ishida T, Ogura S, Kojima T, Okamoto Y, Fujita Y, Dosaka-akita $\mathrm{H}$, Isobe $\mathrm{H}$ and Nishimura $\mathrm{M}$ : A phase II trial of gefitinib as first-line therapy for advanced non-small cell lung cancer with epidermal growth factor receptor mutations. Br J Cancer 95: 998-1004, 2006.
8. Sordella R, Bell DW, Haber DA and Settleman J: Gefitinibsensitizing EGFR mutations in lung cancer activate anti-apoptotic pathways. Science 305: 1163-1167, 2004.

9. Jorissen RN, Walker F, Pouliot N, Garrett TP, Ward CW and Burgess AW: Epidermal growth factor receptor: mechanisms of activation and signaling. Exp Cell Res 284: 31-53, 2003.

10. Cappuzzo F, Magrini E, Ceresoli GL, Bartolini S, Rossi E, Ludovini V, Gregorc V, Ligorio C, Cancellieri A, Damiani S, Spreafico A, Paties CT, Lombardo L, Calandri C, Bellezza G, Tonato $\mathrm{M}$ and Crino L: Akt phosphorylation and gefitinib efficacy in patients with advanced non-small-cell lung cancer. J Natl Cancer Inst 96: 1133-1141, 2004.

11. Witta SE, Gemmill RM, Hirsch FR, Coldren CD, Hedman K, Ravdel L, Helfrich B, Dziadziuszko R, Chan DC, Sugita M, Chan Z, Baron A, Franklin W, Drabkin HA, Girard L, Gazdar AF, Minna JD and Bunn PA Jr: Restoring E-cadherin expression increases sensitivity to epidermal growth factor receptor inhibitors in lung cancer cell lines. Cancer Res 66: 944-950, 2006.

12. Therasse P, Arbuck SG, Eisenhauer EA, Wanders J, Kaplan RS, Rubinstein L, Verweij J, van Glabbeke M, van Oosterom AT, Christian MC and Gwyther SG: New guidelines to evaluate the response to treatment in solid tumors. J Natl Cancer Inst 92: 205-216, 2000.

13. Gemma A, Hagiwara K, Ke Y, Burke LM, Khan MA, Nagashima M, Bennett WP and Harris CC: FHIT mutations in human primary gastric cancer. Cancer Res 57: 1435-1437, 1997.

14. Uematsu K, Yoshimura A, Gemma A, Mochimaru H, Hosoya Y, Kunugi S, Matsuda K, Seike M, Kurimoto F, Takenaka K, Koizumi K, Fukuda Y, Tanaka S, Chin K, Jablons DM and Kudoh S: Aberrations in the fragile histidine triad (FHIT) gene in idiopathic pulmonary fibrosis. Cancer Res 61: 8527-8533, 2001.

15. Yoshimura A, Gemma A, Kataoka K, Hosoya Y, Noro R, Seike M, Kokubo Y, Watanabe M and Kudoh S: Mutational analysis of the macrophage scavenger receptor 1 (MSR1) gene in primary lung cancer. J Nippon Med Sch 71: 99-104, 2004.

16. Nagai Y, Miyazawa H, Huqun, Tanaka T, Udagawa K, Kato M, Fukuyama S, Yokote A, Kobayashi K, Kanazawa M and Hagiwara K: Genetic heterogeneity of the epidermal growth factor receptor in non-small cell lung cancer cell lines revealed by a rapid and sensitive detection system, the peptide nucleic acidlocked nucleic acid PCR clamp. Cancer Res 65: 7276-7282, 2005.

17. Mukohara T, Kudoh S, Yamauchi S, Kimura T, Yoshimura N, Kanazawa H, Hirata K, Wanibuchi H, Fukushima S, Inoue K and Yoshikawa J: Expression of epidermal growth factor receptor (EGFR) and downstream-activated peptides in surgically excised non-small-cell lung cancer (NSCLC). Lung Cancer 41: 123-130, 2003.

18. Argiris A, Hensing T, Yeldandi A, Patel S, Raji A, Sturgis C, Masters G, Gooding W, Pins M and Kolesar J: Combined analysis of molecular and clinical predictors of Gefitinib activity in advanced non-small cell lung cancer: Epidermal Growth Factor Receptor mutations do not tell the whole story. J Thorac Oncol 1: 52-60, 2006

19. Deeb G, Wang J, Ramnath N, Slocum HK, Wiseman S, Beck A and Tan D: Altered E-cadherin and epidermal growth factor receptor expressions are associated with patient survival in lung cancer: a study utilizing high-density tissue microarray and immunohistochemistry. Mod Pathol 17: 430-439, 2004.

20. Mitsudomi T, Kosaka T, Endoh H, Horio Y, Hida T, Mori S, Hatooka S, Shinoda M, Takahashi T and Yatabe Y: Mutations of the epidermal growth factor receptor gene predict prolonged survival after gefitinib treatment in patients with non-small-cell lung cancer with postoperative recurrence. J Clin Oncol 23: 2513-2520, 2005.

21. Takano T, Ohe Y, Sakamoto H, Tsuta K, Matsuno Y, Tateishi U, Yamamoto S, Nokihara H, Yamamoto N, Sekine I, Kunitoh H, Shibata T, Sakiyama T, Yoshida T and Tamura T: Epidermal growth factor receptor gene mutations and increased copy numbers predict gefitinib sensitivity in patients with recurrent non-small-cell lung cancer. J Clin Oncol 23: 6829-6837, 2005.

22. Tokumo M, Toyooka S, Kiura K, Shigematsu H, Tomii K, Aoe M, Ichimura K, Tsuda T, Yano M, Tsukuda K, Tabata M, Ueoka H, Tanimoto M, Date H, Gazdar AF and Shimizu N: The relationship between epidermal growth factor receptor mutations and clinicopathologic features in non-small cell lung cancers. Clin Cancer Res 11: 1167-1173, 2005. 
23. Han SW, Kim TY, Hwang PG, Jeong S, Kim J, Choi IS, Oh DY, Kim JH, Kim DW, Chung DH, Im SA, Kim YT, Lee JS, Heo DS, Bang YJ and Kim NK: Predictive and prognostic impact of epidermal growth factor receptor mutation in non-small-cell lung cancer patients treated with gefitinib. J Clin Oncol 23: 2493-2501, 2005.

24. Taron M, Ichinose Y, Rosell R, Mok T, Massuti B, Zamora L, Mate JL, Manegold C, Ono M, Queralt C, Jahan T, Sanchez JJ, Sanchez-Ronco M, Hsue V, Jablons D, Sanchez JM and Moran T: Activating mutations in the tyrosine kinase domain of the epidermal growth factor receptor are associated with improved survival in gefitinib-treated chemorefractory lung adenocarcinomas. Clin Cancer Res 11: 5878-5885, 2005.

25. Bremnes RM, Veve R, Gabrielson E, Hirsch FR, Baron A, Bemis L, Gemmill RM, Drabkin HA and Franklin WA: Highthroughput tissue microarray analysis used to evaluate biology and prognostic significance of the E-cadherin pathway in nonsmall-cell lung cancer. J Clin Oncol 20: 2417-2428, 2002.

26. Kase S, Sugio K, Yamazaki K, Okamoto T, Yano T and Sugimachi K: Expression of E-cadherin and B-catenin in human non-small cell lung cancer and the clinical significance. Clin Cancer Res 6: 4789-4796, 2001.

27. Sulzer MA, Leers MPG, van Noord JA, Bollen EC and Theunissen PH: Reduced E-cadherin expression is associated with increased lymph node metastasis and unfavorable prognosis in non-small cell lung cancer. Am J Respir Crit Care Med 157: 1319-1323, 1998

28. Liu D, Huang C, Kameyama K, Hayashi E, Yamauchi A, Kobayashi S and Yokomise H: E-cadherin expression associated with differentiation and prognosis in patients with non-small cell lung cancer. Ann Thorac Surg 71: 949-954, 2001.

29. Krishnadath KK, Tilanus HW, van Blankenstein M, Hop WC, Kremers ED, Dinjens WN and Bosman FT: Reduced expression of the cadherin-catenin complex in oesophageal adenocarcinoma correlates with poor prognosis. J Pathol 182: 331-338, 1997.

30. Nakanishi Y, Ochiai A, Akimoto S, Kato H, Watanabe H, Tachimori Y, Yamamoto S and Hirohashi S: Expression of Ecadherin, a-catenin, $\beta$-catenin and plakoglobin in esophageal carcinomas and its prognostic significance: immunohistochemical analysis of 96 lesions. Oncology 54: 158-165, 1997.

31. Jawhari A, Jordan S, Poole S, Browne P, Pignatelli M and Farthing MJ: Abnormal immunoreactivity of the E-cadherincatenin complex in gastric carcinoma: relationship with patient survival. Gastroenterology 112: 46-54, 1997.
32. Mayer B, Johnson JP, Leitl F, Jauch KW, Heiss MM, Schildberg FW, Birchmeier W and Funke I: E-cadherin expression in primary and metastatic gastric cancer: downregulation correlates with cellular dedifferentiation and glandular disintegration. Cancer Res 53: 1690-1695, 1993.

33. Hiscox S and Jiang WG: Expression of E-cadherin, $\alpha, \beta$ and $\gamma$ catenin in human colorectal cancer. Anticancer Res 17: 1349-1354, 1997.

34. Ashida K, Terada T, Kitamura $\mathrm{Y}$ and Kaibara N: Expression of E-cadherin, $\alpha$-catenin, $\beta$-catenin and CD44 (standard and variant isoforms) in human cholangiocarcinoma: an immunohistochemical study. Hepatology 27: 974-982, 1998.

35. Gunji N, Oda T, Todoroki T, Kanazawa N, Kawamoto T, Yuzawa K, Scarpa A and Fukao K: Pancreatic carcinoma: correlation between E-cadherin and $\alpha$-catenin expression status and liver metastasis. Cancer 82: 1649-1656, 1998.

36. Cheng L, Nagabhushan M, Pretlow TP, Amini SB and Pretlow TG: Expression of E-cadherin in primary and metastatic prostate cancer. Am J Pathol 148: 1375-1380, 1996.

37. Richmond PJ, Karayiannakis AJ, Nagafuchi A, Kaisary AV and Pignatelli M: Aberrant E-cadherin and $\alpha$-catenin expression in prostate cancer: correlation with patient survival. Cancer Res 57: 3189-3193, 1997.

38. Fedor-Chaiken M, Hein PW, Stewart JC, Brackenburv R and Kinch MS: E-cadherin binding modulates EGF receptor activation. Cell Commun Adhes 10: 105-118, 2003.

39. Andl CD and Rustgi AK: No one-way street: Cross-talk between E-cadherin and receptor tyrosine kinase (RTK) signaling. A mechanism to regulate RTK activity. Cancer Biol Ther 4: 28-31, 2006.

40. Qian X, Karpova T, Sheppard AM, McNally J and Lowy DR: E-cadherin mediated adhesion inhibits ligand-dependent activation of diverse receptor tyrosine kinases. EMBO J 23: 1739-1748, 2004.

41. Shiozaki H, Kadowaki T, Doki Y, Inoue M, Tamura S, Oka H, Iwazawa T, Matsui S, Shimaya K and Takeichi M: Effect of epidermal growth factor on cadherin-mediated adhesion in a human oesophageal cancer cell line. Br J Cancer 71: 250-258, 1995.

42. Jones JL, Royall JE and Walker RA: E-cadherin relates to EGFR expression and lymph node metastasis in primary breast carcinoma. Br J Cancer 74: 1237-1241, 1996.

43. Al Moustafa AE, Yen L, Benlimame N and Alaoui-Jamali MA Regulation of E-cadherin/catenin complex patterns by epidermal growth factor receptor modulation in human lung cancer cells. Lung Cancer 37: 49-56, 2002. 